\title{
ADAPTIVE SELLING BEHAVIOUR: A STUDY AMONG SALESPERSON IN PHARMACEUTICAL INDUSTRY
}

\author{
Kok Leong Wong* and Cheng Ling Tan \\ Graduate School of Business, Universiti Sains Malaysia, \\ 11800 USM Pulau Pinang, Malaysia \\ *Corresponding author: klwong_pg@yahoo.com
}

Published online: 29 June 2018

To cite this article: Wong, K.L. and Tan, C.L. (2018). Adaptive selling behaviour: A study among salesperson in pharmaceutical industry. Asian Academy of Management Journal, 23(1), 1-22. https://doi.org/10.21315/aamj2018.23.1.1

To link to this article: https://doi.org/10.21315/aamj2018.23.1.1

\begin{abstract}
Sales management of today is facing challenging issues of sales force management in order to achieve the desired firm's business performance. A firm's business performance is closely associated to how effective the sales force is in performing their selling tasks. As salespersons need to face different customers and engage in different sales situations, salespersons must be flexible and be able to adapt their selling styles in all different situations. Salespersons' behaviour in adapting their selling approaches is known as adaptive selling behaviour. The ability of salespersons in performing their selling tasks hinges on their capability in practicing adaptive selling behaviour during and across the sales interactions with customers. This study focuses on the managerial practices of control and empowerment, and examines their simultaneous influence on salesperson's adaptive selling behaviour. This study was conducted on a sample of pharmaceutical salespersons in Malaysia, whose customers are healthcare professionals. Nine pharmaceutical firms participated in the survey with a total of 154 responses received. Results revealed that control practice of activity control and empowerment practices of promoting participation in decision-making, expressing confidence, and providing autonomy had significant relationships with salesperson's practice of adaptive selling behaviour. Implications, limitations of the research, and improvements for future studies were discussed.
\end{abstract}

Keywords: salesperson, adaptive selling behaviour, control, empowerment, social exchange theory

(C) Asian Academy of Management and Penerbit Universiti Sains Malaysia, 2018. This work is licensed under the terms of the Creative Commons Attribution (CC BY) (http://creativecommons. org/licenses/by/4.0/). 


\section{INTRODUCTION}

Typically, a firm's sales unit comprises a sales manager who is overseeing a group of salespersons. As the firm's sales unit is responsible for generating a specific amount of revenue, the sales manager and the group of salespersons are accountable to meet the agreed upon sales quota. While the contribution of the firm's sales unit is revenue and profit for the firm, there is a significant cost associated in maintaining a sales unit. The cost involves hiring, managing, and compensating the sales force. On an increasingly trend, the cost of maintaining a sales unit is escalating. However, performance and effectiveness of sales force are still far from satisfactory (Accenture, 2012).

Generally, a salesperson is employed as a marketing agent to be involved in personal selling as well as to strategise the firm's marketing activities. The involvement of these salespersons are more effective than any other promotional mix as this is due to the human interactions between the three parties namely, the firms, external customers, and the targeted customers (Zoltners, Sinha, \& Lorimer, 2009). Hughes (2013) stated that the "pull" effects of a firm's product depends heavily on advertising whereas the "push" efforts is via the promotional and selling a product's values to the targeted customers.

Zoltners et al. (2009) stated that a firm salesperson has to play several roles. Firstly, they are the firm's financial contributors. A firm's financial success is largely dependent on the effectiveness of the salespersons in generating revenue and profits. Second, salespersons are the change agent in generating the customers' purchasing decision via their convincing power in closing the sales. Third, salespersons play the dual advocacy role of boundary spanner by matching and satisfying both the internal firm's supply and the external customer's demands (Stan, Evans, Arnold, $\&$ McAmis, 2012). Last but not the least, salespersons are regarded as knowledge brokers (Verbeke, Dietz, \& Verwaal, 2010) who are the valued two-way communication agents that link their firms and the customers (Ingram, LaForge, Avila, Schwepker Jr., \& Williams, 2012). However, there is limited sales literature published as compared to marketing literature. Zoltners, Sinha, and Lorimer (2013) mentioned that only $3 \%$ of the articles from four established journals have been published in the area of sales force for the last 10 years. Correspondingly, Fogel, Hoffmeister, Rocco, and Strunk (2012) stated only one article was found to be in the area of sales from the 48 published articles in the year 2011. Generally, past studies have found that Western countries have conducted studies in the area of understanding the factors of salesperson performance as compared to developing countries which has limited studies. Hence, based on these important functions of salespersons to a firm, a study examining the effectiveness of salesperson warrants further research. 


\section{LITERATURE REVIEW}

\section{Salesperson's Adaptive Selling Behaviour}

In business-to-business (B2B) marketing approach, salespersons are primarily involved in personal selling, dealing directly with customers who are also the decision-makers. During the face-to-face interactions with the customers, salespersons engage in specific selling behaviours. Wren and Simpson (1996) explained that the behaviours showed by the salespersons in the course of working have been found to influence sales effectiveness and is known as selling behaviours.

Weitz $(1978,1979,1981)$ had broadly studied on the selling behaviours. The most significant contributor of the effectiveness of sales comes from salesperson adaptiveness when the selling takes place (Wren \& Simpson, 1996). The concept of applying adaptiveness in selling behaviours is known as adaptive selling behaviour (or ASB).

Sujan (1986) explained the changing of selling behaviours during a customer interaction based upon perceived information about the selling situations is known as adaptive selling behaviour. Engaging in adaptive selling behaviour enables the salespersons to take advantage of the unique nature of personal selling interactions as a means of communicating the customised message to the customers. The effectiveness of a salesperson's adaptive nature in the personal selling process hinges on the salespersons' ability to be sensitive to the buyers' personalities and moods, and be responsive to the dynamics of the information exchange during the interaction (Porter, Wiener, \& Frankwick, 2003). A salesperson with high selling adaptability is capable of adjusting his or her selling behaviours when interacting with the customers (Spiro \& Weitz, 1990). As engaging in adaptive selling behaviour has been found to have a positive impact on a salesperson's performance (Singh \& Das, 2013), research into what drives a salesperson to engage in adaptive selling behaviour warrants further investigation.

\section{Organisational Factors of Sales Managerial Practices}

Scholars supported the notion that performance and effectiveness of salespersons should be investigated based on organisational factors within the control of the sales management and not other external factors (Cravens, Le Meunier-FitzHugh, \& Piercy, 2011). Managerial practices cover a wide scope of activities comprising activities and tasks which include a variety of assignments and can constitute key aspects of the sales management works (Dubinsky, 1999). Despite knowing the importance of managerial practices, there is a dearth of empirical studies examining 
the influence of sales managerial practices on salesperson's selling behaviour and performance (Avlonitis \& Panagopoulos, 2007).

\section{The Paradox of Control and Empowerment Practices}

Based on the electronic database search and literature review, past studies conducted in relation to the influence of managerial practices found that control and empowerment were the most common managerial practices studied. However, control and empowerment were commonly studied as separate research streams. With the exception of the studies by Lambe, Webb, and Ishida (2009) who studied sales team performance and Simintiras, Ifie, Watkins, and Georgakas (2013) who studied retail salespersons' performance, there was no empirical studies which integrated both the control and empowerment together. This was because control and empowerment were often seen as contradictory elements of two conflicting managerial practices (Nash, Brown, \& Sutton, 2014).

Tannenbaum and Schmidt (1973) highlighted on the nature of managerial behaviours and styles through the "Leadership Continuum Model." This model proposes two extreme ends of the management continuum. It shows managercentred style of autocratic leadership at one end whereas subordinate-centred style of democratic leadership on the other end, and both ends are mutually exclusive as management needs to choose either one. This situation was often being referred to as a dilemma.

However, scholars found that dilemma often led to a sense of organisational tension and paralysis because there were associated opportunity costs and benefits involved (Smith \& Lewis, 2011). More recent case studies and qualitative research revealed that the more managers stressed one side, the more this accentuated the opposite side, and that often caused the paradoxical nature to surface (Lewis \& Smith, 2014). Smith and Lewis (2011) termed it as "paradox," which they categorised it as "contradictory, yet interrelated elements (dualities) that need to exist simultaneously and persist over time" (p. 387). Scholars subsequently proposed that paradox should be managed in a balanced manner and co-exist, rather than to be resolved by choosing either one. However, empirical studies examining the elements of paradox of control and empowerment in the context of sales force management have been generally lacking (Lambe et al., 2009; Simintiras et al., 2013). Hence, the present study focuses on examining both the influence of control and empowerment practices on salesperson's adaptive selling behaviour. 


\section{Control Practices and Salesperson's Adaptive Selling Behaviour}

Piercy, Cravens, and Lane (2012) defined control as a tool used by sales management to manage and control the firm's resources more efficiently. Firms regulate the behaviour of their salespersons in order to meet their business objectives via control process (Challagalla \& Shervani, 1997). Control, in the form of management involvement and supervision, should provide guidance and motivation to the salespersons to perform better (Baldauf, Cravens, \& Piercy, 2001). In line with the underlying social exchange theory, salespersons should react in a positive manner and reciprocate the influence of supervisory control. A form of salesperson behavioural performance is known as salesperson's adaptive selling behaviour (Babakus, Cravens, Grant, Ingram, \& LaForge, 1996; Guenzi, Baldauf, \& Panagopoulos, 2014). Hence, salespersons who reciprocate the influence of supervisory control should engage in smart-selling approach in order to achieve the improvement in their performance. Past studies have proven that there is a positive relationship between supervisory control and salesperson's adaptive selling behaviour (Guenzi et al., 2014; Piercy, Low, \& Cravens, 2004; Rouzies \& Macquin, 2003).

Based on the conceptualisation of Jaworski (1988) and refined by Challagalla and Shervani (1996), control practices consist of output control, activity control, and capability control. Output control focuses on achievement of end-results such as sales revenue. Activity control aims to guide salesperson's to achieve sellingrelated tasks and activities while capability control emphasises on attainment of specific abilities and skills of the salespersons crucial for achieving the required outcomes (Fang, Evans, \& Landry, 2005). Both activity control and capability are often being referred to as behaviour control (Challagalla \& Shervani, 1996).

In output control, salespersons are given the freedom to achieve the sales outcomes and salesperson performance is directly measured based on their sales revenue achievements. Salespersons are compensated proportionately based on their achievements. Output control was found to influence positively on salesperson's learning and performance orientation which lead to adaptive selling approach (Jaworski \& Kohli, 1991) and enhance salesperson's learning orientation (Kohli, Shervani, \& Challagalla, 1998). We conceptualise the positive relationship between output control and adaptive selling behaviour to be consistent with the past literature (Kohli et al., 1998). Hence, it is logical to propose that:

H1a: Output control is positively related to salesperson's adaptive selling behaviour. 
In contrast to output control, behaviour control involves relatively close supervision from the sales management in specifying the tasks, activities, abilities, and skills that are expected to be achieved or completed (Miao, 2007). Sales management also constantly provide diagnostic feedback to the salespersons with respect to their progress of the tasks, activities, abilities, and skills (Challagalla \& Shervani, 1996). Past studies have proven that there is a significant positive relationship of behaviour control towards salesperson's adaptive selling behaviour (Babakus et al., 1996; Piercy et al. 2004).

Both activity control and capability would equip salesperson to practice "smart selling" which is a form of adaptive selling behaviour (Rouzies \& Macquin, 2003). Specifically, activity control enables the manager to define and specify a list of tasks and activities which the salesperson is required to perform and accomplish in order to ultimately achieve the desired organisational objectives. The sales manager will supervise and monitor the salesperson's tasks and activities if he or she is complying with the pre-determined selling-related activities. Additionally, sales manager will provide valuable coaching of the different selling situations. Under the manager's guidance and orientation, the salesperson may decide to engage in a different selling approach (Guenzi et al., 2014; Kohli et al., 1998). Thus, the following hypothesis is proposed:

H1b: Activity control is positively related to salesperson's adaptive selling behaviour.

In capability control, the manager will set personalised goals for the individual salesperson with regards to the levels of skills and abilities needed to be mastered by the salesperson. The manager will closely guide, coach, and provide constructive feedbacks to the salesperson (Baldauf et al., 2001; Piercy, Cravens, \& Morgan 1998, 1999). According to Bandura (1977), a salesperson's self-determination, self-efficacy, and competencies will be elevated through capability control. Furthermore, in order to encourage innovation and creative thinking, salespersons are exposed to different scenarios and problems (Sujan, Weitz, \& Kumar, 1994). In Oliver and Anderson (1995) studies, they expressed that by having an essential skills, one should undertake new tactics in overcoming problems and closing a sale. A study by Kohli et al. (1998) found that capability orientation has a positive relationship with salesperson's learning orientation. Hence, the following hypothesis is proposed:

H1c: Capability control is positively related to salesperson's adaptive selling behaviour. 


\section{Empowerment Practices and Salesperson's Adaptive Selling Behaviour}

While control intends to enable the firm to control their resources, empowerment practices provide more autonomy to the salespersons. There are two conceptions of empowerment based on past literature: psychological empowerment (or motivational form of empowerment) and structural empowerment (or relational empowerment). The former refers to the employee's experiences and feelings of being empowered while the latter denotes top management initiatives towards delegation of authority in the top-down hierarchy (Ahearne, Mathieu, \& Rapp, 2005). However, there are limited number of research on the structural empowerment. This current study will emphasis on the conception of structural empowerment examining the initiation of empowerment by the sales management on salespersons.

Based on the conceptualisation of Ahearne (2000) and Ahearne et al. (2005) which was developed based on the original conceptualisation of Hui (1994), empowerment is being conceptualised to comprise of four dimensions: enhancing meaningfulness, promoting participation, expressing confidence, and providing autonomy. Through the practices of empowerment, salespersons are given the flexibility and control over decision-making (Ahearne et al., 2005). Roman and Iacobucci (2010) explained that salesperson will feel confident and motivated with different methods and uses information make available for them to adapt to their selling tactics. Based on the above explanations, it makes sense to propose that all the dimensions of structural empowerment have a positive influence on the practice of adaptive selling behaviour.

This dimension of managerial behaviours aims at enhancing subordinates' sense of purpose and meaningfulness in their work. The subordinates' job roles are respected and valued by informing them on how well their work is aligned with organisational objectives and goals. In order to make a salesperson contribution to be of important, a manager willingness to enhance on the meaningfulness of work will be able to build a great sense of adaptability and self-efficacy (Ahearne et al., 2005). Possessing the feelings of self-efficacy and adaptability, salespersons would be innovative in exploring whatever effective approach with the objectives of achieving the organisational goals upon which the salespersons are ultimately aware that their efforts are valued and important in contributing to the overall firm's success (Spiro \& Weitz, 1990). Thus, the following hypothesis is proposed:

H2a: Enhancing meaningfulness is positively related to salesperson's adaptive selling behaviour. 
Promoting participation encourages employees to participate in problem solving and decision-making process. Vecchio, Justin, and Pearce (2010) stated that self-determination and self-efficacy should be created among salesperson by encouraging them to be part of the company's problem solving team. Salespersons who were given the chance to voice their opinions will have the impression that the company respects their effort during the decision making process. When a customer interaction takes place, salesperson would fully utilise the guidance taught by the managers to showcase their adaptive selling behaviours (Anglin, Stolman, \& Gentry, 1990). Hence, it is plausible to hypothesise that:

$\mathrm{H} 2 \mathrm{~b}$ : Promoting participation is positively related to salesperson's adaptive selling behaviour.

By encouraging and expressing confidence in a subordinate's performance, this will improve the subordinate's self-efficacy and competence perceptions on the job (Kwak, 2011). In the context of the present study, sales management who practices the dimension of expressing confidence focuses on cultivating the individual salesperson's confidence to perform at a higher level and handle challenging tasks. This will then influence their adaptive selling behaviours when meeting the customers. Hence, it is appropriate to propose the following hypothesis:

H2c: Expressing confidence is positively related to salesperson's adaptive selling behaviour.

Providing autonomy aims to minimise administrative constraints so that employees can perform efficiently. This was also supported by Wang and Netemeyer (2002) who noted that job autonomy positively affects salesperson's self-efficacy which then leads to improved sales performance. Vecchio et al. (2010) stated that employees can achieve autonomy by getting rid of some company's rules and regulations that are redundant in command level. With this, employees can achieve their goals more efficient. Hence, it is hypothesise that:

H2d: Providing autonomy is positively related to salesperson's adaptive selling behaviour.

\section{RESEARCH FRAMEWORK}

Figure 1 is developed to incorporate the influence of managerial practices of control and empowerment on salesperson's adaptive selling behaviour. 


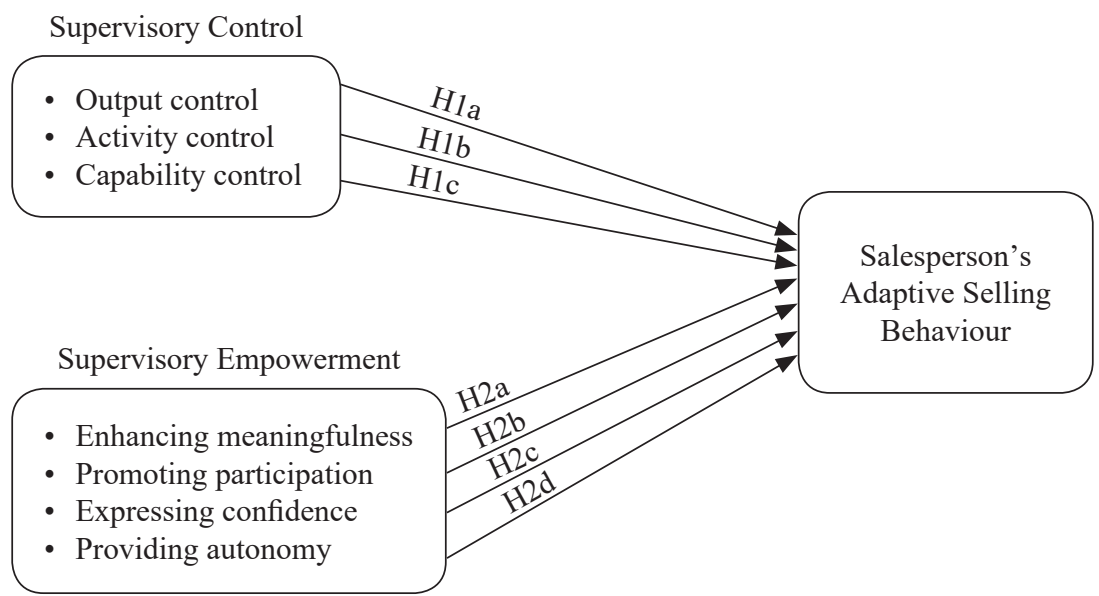

Figure 1. Proposed research framework

Cropanzano and Mitchell (2005) explained the relationships between an organisation and its employees based on the social exchange theory. Managerial practices comprise a broad scope of activities performed by the organisation (or management) on employees with the goal to drive and improve employees' performance. In order for employees to achieve the desired performance, employees need to behave in a certain positive manner. The main view of social exchange theory is the concept of reciprocity between the two parties (Blau, 1964). When the firms treat their employees well, there is a high possibility that the employees will display a high level of commitment towards their firms which will lead to positive work performance as well as achieving a positive behaviour. This study aims to examine the outcome of the salespersons engaging in adaptive selling behaviour as a result of the influence of managerial practices of control and empowerment.

\section{METHODOLOGY}

\section{Measures}

The present study is a quantitative research utilising survey questionnaires to gather the required data. The survey questionnaire consists of a total of 44 items. It begins with 12 items of demographic information and followed by 32 items of close-ended questions measured using Likert scale. Out of these 32 items, 15 items measured control practices, 12 items measured empowerment practices, and 5 items measured salesperson's adaptive selling behaviour. The measure of control practices was adapted from Challagalla and Shervani (1996), which 
has a Cronbach's alpha of 0.94 (output control), 0.86 (activity control), and 0.92 (capability control). The measure of empowerment practices was adapted from Ahearne et al. (2005) which has an overall Cronbach's alpha of 0.92. Measure of salesperson's adaptive selling behaviour was adapted from Robinson Jr., Marshall, Moncrief, and Lassk (2002), which introduced the shortened version measure of the full adaptive selling behaviour scale developed by Spiro and Weitz (1990). The shortened version has a comparatively high Cronbach's alpha value of 0.84 as the full version. To reduce potential common method variance issue arising from the error due to the same respondent answering the same scale, different Likert scales were used. Control practices and empowerment practices were measured using a 7-point Likert scale while adaptive selling behaviour was measured using a 6-point Likert scale.

\section{Sample and Data Collection}

The present study was a correlational and cross-sectional study. It was conducted on a sample of pharmaceutical salespersons in Malaysia as the individual unit of analysis. The salespersons' customers are healthcare professionals located at clinics, and public and private hospitals. In the pharmaceutical industry, the use of salespersons to promote pharmaceutical products and services face-to-face to the healthcare professionals is a common marketing practice. Since pharmaceutical salespersons interact face-to-face with healthcare professionals in the B2B marketing approach, the pharmaceutical industry is one of the most appropriate industry where this research can be applied. The study involved distribution of survey questionnaires to individual salespersons working as full-time employees in the pharmaceutical firms in Malaysia. There were 42 pharmaceutical firms listed in the Pharmaceutical Association of Malaysia (PhAMA) website. The human resource managers of all these firms were contacted and sought for permission to get their salespersons to participate. Out of the 42 firms, only 9 firms agreed to participate in the survey. Based on the number of salespersons provided by the participating firms, a total of 320 hard copies of questionnaires were mailed to the 9 participating firms. In a period of three months, a total of 154 responses were received. This yielded a response rate of $48.12 \%$.

\section{ANALYSIS AND RESULTS}

\section{Data Screening and Descriptive Statistics}

The checking for incomplete response, missing data, and outliers was conducted via data screening. Sixteen responses were found to be incomplete with a lot of 
missing data, thus had to be discarded. Five responses were found to consist of outliers above the \pm 3 standardised values and had to be dropped. The final number of usable responses was 133. All the 133 responses were checked for common method variance issue using Harman's Single Factor test in SPSS and confirmed no serious issue of common method variance based on the guidelines (Podsakoff, MacKenzie, Lee, \& Podsakoff, 2003). Out of the 133 respondents, female and male respondents recorded at $61.7 \%$ and $38.3 \%$ respectively. Meanwhile, $60.9 \%$ of the respondents were single and $32.3 \%$ were married. Majority of the respondents are aged $26-30$ years $(34.6 \%)$, followed by those aged $31-35$ years (24.8\%), and 21-25 years (13.5\%). The results showed that the sales experience of respondents between 5 to 10 years and those with less than 5 years is $39.1 \%$ and $28.6 \%$ respectively. A large majority of the respondents $(63.2 \%)$ have been working with the company for less than 5 years and $26.3 \%$ have been attached to the company for between 5 to 10 years. As for academic qualification, the majority of them are holding a bachelor's degree (57.9\%) and minority are masters' degree holders $(7.5 \%)$.

\section{Results of the Measurement Model}

SmartPLS was used to perform the tests on the measurement model to check for the reliability and validity of the items. Factor loadings of each item, average variance extracted (AVE), and composite reliability (CR) were checked for each construct. Items with loadings less than 0.5 were removed to make sure the AVE values achieved at least 0.5 and $\mathrm{CR}$ values were at least 0.7 (Hair, Black, Babin, $\&$ Anderson, 2010). One item each from the construct of output control, activity control, and adaptive selling behaviour were deleted. Results as shown in Tables 1 and 2 confirmed that the measurement model possesses convergent validity and discriminant validity.

\section{Results of the Structural Model}

Subsequently, a bootstrapping technique of 1,000 subsamples was performed in SmartPLS to test the structural model in order to find out the path coefficients and significance of the paths. The results of bootstrapping are shown in Table 3. Next, the blindfolding technique was performed to check the predictive relevance of the proposed model. The results of blindfolding as shown in Table 4 , indicated that the proposed model had good predictive relevance. 
Kok Leong Wong and Cheng Ling Tan

Table 1

Summary of SmartPLS: Convergent validity and item reliability

\begin{tabular}{|c|c|c|c|c|}
\hline Construct & Items & Main loadings & AVE & $\mathrm{CR}$ \\
\hline \multirow[t]{5}{*}{ Output control (OC) } & $\mathrm{OC} 1$ & 0.844 & 0.592 & 0.851 \\
\hline & $\mathrm{OC} 2$ & 0.749 & & \\
\hline & OC3 & 0.845 & & \\
\hline & $\mathrm{OC} 4$ & 0.617 & & \\
\hline & OC5 & Deleted & & \\
\hline \multirow[t]{5}{*}{ Activity control (AC) } & $\mathrm{AC} 1$ & 0.664 & 0.584 & 0.848 \\
\hline & $\mathrm{AC} 2$ & 0.789 & & \\
\hline & $\mathrm{AC} 3$ & 0.774 & & \\
\hline & $\mathrm{AC} 4$ & Deleted & & \\
\hline & AC5 & 0.819 & & \\
\hline \multirow[t]{5}{*}{ Capability control (CC) } & $\mathrm{CC} 1$ & 0.728 & 0.542 & 0.855 \\
\hline & $\mathrm{CC} 2$ & 0.690 & & \\
\hline & $\mathrm{CC} 3$ & 0.749 & & \\
\hline & $\mathrm{CC} 4$ & 0.731 & & \\
\hline & $\mathrm{CC} 5$ & 0.780 & & \\
\hline \multirow[t]{3}{*}{ Meaningfulness (MN) } & MN1 & 0.841 & 0.623 & 0.831 \\
\hline & MN2 & 0.795 & & \\
\hline & MN3 & 0.727 & & \\
\hline \multirow[t]{3}{*}{ Participation (PT) } & PT1 & 0.675 & 0.565 & 0.795 \\
\hline & PT2 & 0.731 & & \\
\hline & PT3 & 0.841 & & \\
\hline \multirow[t]{3}{*}{ Confidence (CD) } & $\mathrm{CD} 1$ & 0.847 & 0.677 & 0.863 \\
\hline & $\mathrm{CD} 2$ & 0.836 & & \\
\hline & CD3 & 0.784 & & \\
\hline \multirow[t]{3}{*}{ Autonomy (AU) } & AU1 & 0.791 & 0.593 & 0.814 \\
\hline & AU2 & 0.760 & & \\
\hline & AU3 & 0.760 & & \\
\hline \multirow[t]{5}{*}{ Adaptive selling behaviour (ASB) } & ASB1 & Deleted & 0.504 & 0.876 \\
\hline & ASB2 & 0.803 & & \\
\hline & ASB3 & 0.773 & & \\
\hline & ASB4 & 0.660 & & \\
\hline & ASB5 & 0.723 & & \\
\hline
\end{tabular}

Note: Main loadings $>0.5 ; \mathrm{AVE}>0.5 ; \mathrm{CR}>0.7 ; \mathrm{R}^{2}{ }_{\text {(Performance) }}=0.523$ 
Table 2

Summary of SmartPLS: Discriminant validity of constructs based on Fornell-Larcker criterion

\begin{tabular}{lcccccccccc}
\hline $\begin{array}{l}\text { Fornell-Larcker } \\
\text { criterion } \\
\text { discriminant } \\
\text { validity }\end{array}$ & Mean & SD & 1 & 2 & 3 & 4 & 5 & 6 & 7 & 8 \\
\hline $\begin{array}{l}\text { 1. ASB } \\
\text { 2. AC }\end{array}$ & 5.055 & 0.391 & $\mathbf{0 . 7 1 9}$ & & & & & & & \\
3. AU & 5.367 & 0.468 & 0.422 & $\mathbf{0 . 7 6 4}$ & & & & & & \\
4. CC & 5.335 & 0.570 & 0.451 & 0.467 & $\mathbf{0 . 7 7 0}$ & & & & & \\
5. CD & 5.179 & 0.588 & 0.226 & 0.503 & 0.560 & $\mathbf{0 . 7 3 6}$ & & & & \\
6. MN & 5.122 & 0.674 & 0.487 & 0.461 & 0.489 & 0.461 & $\mathbf{0 . 8 2 3}$ & & & \\
7. OC & 5.488 & 0.527 & 0.343 & 0.467 & 0.634 & 0.517 & 0.492 & $\mathbf{0 . 7 8 9}$ & & \\
8. PT & 5.604 & 0.569 & 0.075 & 0.385 & 0.294 & 0.514 & 0.352 & 0.297 & $\mathbf{0 . 7 6 9}$ & \\
\hline
\end{tabular}

Notes: (1) Diagonal numbers in bold represent the square root of the AVE, while off-diagonals represent the correlations. (2) ASB: adaptive selling behaviour; AC: activity control; AU: autonomy; CC: capability control; CD: confidence; MN: meaningfulness; OC: output control; PT: participation

Table 3

Summary of SmartPLS: Path coefficients and hypothesis testing

\begin{tabular}{lcccccc}
\hline Hypothesis & $\begin{array}{c}\text { Hypothesised } \\
\text { path }\end{array}$ & $\begin{array}{c}\text { Beta } \\
\text { coefficient }\end{array}$ & $t$-value & $p$-value & Stat. Sig. & $\begin{array}{c}\text { Hypothesis test } \\
\text { results }\end{array}$ \\
\hline H1a & AC $\rightarrow$ ASB & 0.248 & $2.814^{* *}$ & 0.002 & Significant & Supported \\
H1b & CC $\rightarrow$ ASB & -0.157 & 1.539 & 0.062 & Not significant & Not supported \\
H1c & OC $\rightarrow$ ASB & -0.174 & 1.355 & 0.088 & Not significant & Not supported \\
H2a & MN $\rightarrow$ ASB & -0.062 & 0.598 & 0.275 & Not significant & Not supported \\
H2b & PT $\rightarrow$ ASB & 0.166 & $1.779^{*}$ & 0.038 & Significant & Supported \\
H2c & CD $\rightarrow$ ASB & 0.340 & $3.604^{* *}$ & 0.000 & Significant & Supported \\
H2d & AU $\rightarrow$ ASB & 0.288 & $3.143^{* *}$ & 0.001 & Significant & Supported \\
\hline
\end{tabular}

Note: $* *=p<0.01(t$-value $>2.33) ; *=p<0.05(1.65<t$-value $<2.33)$ (based on one-tailed test) 
Table 4

Summary of SmartPLS: Predictive relevance of the model

\begin{tabular}{lccccc}
\hline $\begin{array}{l}\text { Exogenous } \\
\text { variable }\end{array}$ & $\begin{array}{c}\text { Endogenous } \\
\text { variable }\end{array}$ & $\begin{array}{c}\text { Beta } \\
\text { coefficient }\end{array}$ & $\mathrm{R}^{2}$ & $\mathrm{Q}^{2}$ & $\begin{array}{c}\text { Predictive } \\
\text { relevance }\end{array}$ \\
\hline $\mathrm{OC}$ & & -0.174 & 0.523 & 0.240 & Yes \\
AC & & 0.248 & & & \\
CC & & -0.157 & & & \\
MN & ASB & -0.062 & & & \\
PT & & 0.166 & & & \\
CD & & 0.340 & & & \\
AU & & 0.288 & & & \\
\hline
\end{tabular}

Note: Blindfolding omission distance $=6$

\section{DISCUSSION, IMPLICATIONS, AND LIMITATIONS}

Based on the data analysis, only activity control, promoting participation, expressing confidence, and providing autonomy were determined to have the statistically significant direct influences; there were no significant influence of output control, capability control, and enhancing meaningfulness. The results support hypotheses $\mathrm{H} 1 \mathrm{a}, \mathrm{H} 2 \mathrm{~b}, \mathrm{H} 2 \mathrm{c}$, and $\mathrm{H} 2 \mathrm{~d}$, while hypotheses $\mathrm{H} 1 \mathrm{~b}, \mathrm{H} 1 \mathrm{c}$, and H2a were not supported.

The significant and positive relationship of activity control was aligned with the past results which supported the positive relationship between activity control and adaptive selling behaviour (Guenzi et al., 2014), the positive relationship between behaviour-based control and behavioural performance which adaptive selling behaviour is part of the dimensions (Babakus et al., 1996; Baldauf et al., 2001; Grant \& Cravens, 1996; Piercy et al., 1998, 1999; Piercy et al., 2004), as well as the positive relationship between behavioural control and "working smarter" behaviour where this behaviour is recognised as a form of adaptive selling (Rouzies $\&$ Macquin, 2003).

Additionally, empowerment practices, expressing confidence, providing autonomy, and promoting participation were found to have positive significant relationship with adaptive selling behaviour. This was similar to the findings of Ahearne et al. (2005) which revealed a positive relationship between the practices of empowerment on salesperson's adaptability. With respect to autonomy and self-efficacy, past research had provided the empirical evidence to support the empowerment-adaptability relationship (Scott \& Bruce, 1994; Chebat \& Kollias, 
2000). Besides, the empirical support was found for the positive relationship between tolerance of freedom and adaptive selling among salespersons, as well as the positive relationship between managerial encouragement and adaptive selling.

To explain the insignificant relationships of capability control, output control, and enhancing meaningfulness with adaptive selling behaviour, the following justifications can be offered. Capability control is usually seen as a long-standing development on the skills and abilities of selling of the salespersons, and unlikely to affect the salespersons to engage in adaptive selling behaviour in the short term. Capability control could probably see by the salespersons as a way in investing their time and effort to boost future performance, and therefore, an increase in the capability control practice by the sales management would not motivate the salespersons to engage in adaptive and innovative approaches in their current sales interactions with customers. Similar rational reason to explain this observation on the insignificant output control on adaptive selling behaviour. The increase in output control by sales management was seen to exert more work stress and pressure on the salespersons to achieve the required performance and discourage them from exploring different innovative approaches to selling styles. Both these findings support the findings from Miao (2007) and Miao and Evans (2013) where capability control and output control do not affect adaptive selling behaviour.

The unexpected outcome where enhancing meaningfulness has no significant positive relationship with adaptive selling behaviour can be explained as follows. Since enhancing meaningfulness anticipates to create awareness about the importance of the salespersons' contributions, this practice tends to lead to future improvement in salespersons' performance, but may not be seen as critical and related in the near-term flexible and innovative ways of changing to the different approach of selling. The feeling of being an important member of the firm does not necessarily lead to the practice of adaptive selling behaviour.

Based on the findings of this research, a few inferences can be drawn for the benefit of the academics and researchers. Firstly, this research framework was developed based on social exchange theory to address how managerial practices influence salesperson performance. It was conceptualised based on the underlying theory that salespersons would reciprocate the positive influence of managerial practices through the engagement of adaptive selling behaviour which has a positive impact on salesperson performance. Secondly, this research contributes empirically to the present knowledge of control and empowerment which have been popularised as the paradox of modern management concept. Although not all dimensions of control and empowerment were found to be significant, this research managed to confirm that in the context of complex selling such as in the pharmaceutical 
industry, both control and empowerment need to co-exist in order to effectively affect salespersons to engage in adaptive selling behaviour.

A review of the results conclusively showed that managerial practices of activity control, promoting participation, expressing confidence, and providing autonomy are important managerial practices to drive a higher level of salesperson performance through engagement of adaptive selling behaviour. Sales management must focus on providing coaching, mentoring and guidance, especially to young salespersons to make sure task-oriented selling activities are accomplished. Obviously, giving opportunities to salespersons to participate in decision making would lead to enhance self-confidence. There is a critical need for sales management to instill a high level of confidence and allow a certain amount of autonomy to the salespersons so that the salespersons can act within the boundaries of the firms and yet be innovative to explore sales related issues. All these practices lead to enhanced salesperson's feeling of self-efficacy and confidence which encourage salespersons to be flexible, innovative, and adaptive to the changing nature of the selling situations.

This study has encountered several limitations. These limitations open the door to opportunities for future improvement in the similar area of salesperson performance research. Firstly, this research is being limited by the cross-sectional nature of the study. The issue with the cross-sectional study is, perceptions or knowledge of individual about managerial practices may change or be influenced as a result of certain activities such as a meeting or a training session. Secondly, this study was a self-reported study. Although the Harman's Single Factor test showed no serious common method variance issue, there is still some amount of response biases from individual respondents in reporting their own performance. Thirdly, the generalisation of this study to the whole population posed some obvious limitations. Since the data collection through census method was only performed on the nine participating firms, the salespersons of the remaining non-participating firms were not included. Moreover, most of the respondents were fresh salespersons. This is a survey limitation in the pharmaceutical industry where the majority of the salespersons are fresh and inexperienced. Therefore, it is a challenge to obtain an equal distribution of age and work experience of the samples.

Future research can be conducted to obtain data on salesperson performance from the sales managers while the data on managerial practices be evaluated by the salespersons. Data should also be collected over a longer period of time in order to examine if managerial practices are having any significant impacts on salesperson's adaptive selling behaviour. Improvement in data collection method can also be done by trying to collect data from respondents located in the other 
states of Malaysia, particularly in East Malaysia to obtain a broader demographic distribution of the respondents. Since the data collection of the present study relied on the help of the human resource managers of the participating firms, the human resource managers were the gate-keepers of their firms as many refused to permit their salespersons to take part. Hence, future research should consider to approach the salespersons directly or using online survey approach.

\section{CONCLUSION}

While there are several challenges to improving salesperson performance through the engagement of adaptive selling behaviour, it is important for sales management to make sure their efforts bear fruits by managing their salespersons effectively with the appropriate managerial practices of control and empowerment. Although control and empowerment were perceived to be contradictory elements in management approach, the context of modern management calls for the co-existence of both control and empowerment in order to enhance salesperson performance through engaging in adaptive selling behaviour. This research managed to shed light to confirm that activity control (control practices), promoting participation, expressing confidence, and providing autonomy (empowerment practices) are important managerial practices that should co-exist to influence salespersons to engage in the positive behaviour of adaptive selling.

\section{REFERENCES}

Accenture. (2012). Connecting the dots on sales performance. Retrieved 13 October 2013 from http://www.accenture.com/us-en/Pages/insight-connecting-dots-salesperformance.aspx.

Ahearne, M.J. (2000). An examination of the effects of leadership empowerment behaviors and organizational citizenship behaviors on sales team performance. Unpublished $\mathrm{PhD}$ dissertation, Indiana University, USA.

Ahearne, M.J., Mathieu, J., \& Rapp, A. (2005). To empower or not to empower your sales force? An empirical examination of the influence of leadership empowerment behavior on customer satisfaction and performance. Journal of Applied Psychology, 90(5), 945-955. https://doi.org/10.1037/0021-9010.90.5.945

Anglin, K.A., Stolman, J.J., \& Gentry, J.W. (1990). The congruence of manager perception of salesperson performance and knowledge-based measures of adaptive selling. Journal of Personal Selling and Sales Management, 10, 81-90.

Avlonitis, G.J., \& Panagopoulos, N.G. (2007). Exploring the influence of sales management practices on the industrial salesperson: A multi-source hierarchical linear modeling approach. Journal of Business Research, 60(7), 765-775. https://doi. org/10.1016/j.jbusres.2007.02.011 
Babakus, E., Cravens, D.W., Grant, K., Ingram, T.N., \& LaForge, R.W. (1996). Investigating the relationships among sales, management control, sales territory design, salesperson performance, and sales organization effectiveness. International Journal of Research in Marketing, 13(4), 345-363. https://doi.org/10.1016/ S0167-8116(96)00016-X

Baldauf, A., \& Cravens, D.W. (2002). The effect of moderators on the salesperson behavior performance and salesperson outcome performance and sales organization effectiveness relationships. European Journal of Marketing, 36(11/12), 13671388. https://doi.org/10.1108/03090560210445227

Baldauf, A., Cravens, D.W., \& Piercy, N.F. (2001). Examining the consequences of sales management control strategies in European field sales organizations. International Marketing Review, 18(5), 474-508. https://doi.org/10.1108/EUM0000000006042

Bandura, A. (1977). Self-efficacy: Toward a unifying theory of behavioral change. Psychological Review, 84(2), 191-215. https://doi.org/10.1037/0033295X.84.2.191

Blau, P.M. (1964). Exchange and power in social life. New York: John Wiley.

Challagalla, G.N., \& Shervani, T.A. (1996). Dimensions and types of supervisory control: Effects on salesperson performance and satisfaction. The Journal of Marketing, 60(1), 89-105. https://doi.org/10.2307/1251890

Challagalla, G.N., \& Shervani, T.A. (1997). A measurement model of the dimensions and types of output and behavior control: An empirical test in a salesforce context. Journal of Business Research, 39(3), 159-172. https://doi.org/10.1016/S01482963(96)00195-6

Chebat, J.C., \& Kollias, P. (2000). The impact of empowerment on customer contact employees' roles in service organizations. Journal of Service Research, 3(1), 66-81. https://doi.org/10.1177/109467050031005

Cravens, D.W., Le Meunier-FitzHugh, K., \& Piercy, N.F. (2011). The Oxford handbook of strategic sales and sales management. Oxford, UK: Oxford University Press. https://doi.org/10.1093/oxfordhb/9780199569458.001.0001

Cropanzano, R., \& Mitchell, M.S. (2005). Social exchange theory: An interdisciplinary review. Journal of Management, 31(6), 874-900. https://doi. org/10.1177/0149206305279602

Dubinsky, A.J. (1999). Salesperson failure: Sales management is the key. Industrial Marketing Management, 28(1), 7-17. https://doi.org/10.1016/S0019-8501(98) 00018-2

Fang, E., Evans, K.R., \& Landry, T.D. (2005). Control systems' effect on attributional processes and sales outcomes: A cybernetic information-processing perspective. Journal of the Academy of Marketing Science, 33(4), 553-574. https://doi. org/10.1177/0092070305275249

Fogel, S., Hoffmeister, D., Rocco, R., \& Strunk, D.P. (2012). Teaching sales. Harvard Business Review, 90(7), 94-99.

Grant, K., \& Cravens, D.W. (1996). Examining sales force performance in organizations that use behavior-based sales management processes. Industrial Marketing Management, 25(5), 361-371. https://doi.org/10.1016/0019-8501(96)00038-7 
Guenzi, P., Baldauf, A., \& Panagopoulos, N.G. (2014). The influence of formal and informal sales controls on customer-directed selling behaviors and sales unit effectiveness. Industrial Marketing Management, 43, 786-800. https://doi. org/10.1016/j.indmarman.2014.04.014

Hair, J.F., Black, W.C., Babin, B.J., \& Anderson, R.E. (2010). Multivariate data analysis (7th ed.). Upper Saddle River, New Jersey: Prentice Hall.

Hughes, D.E. (2013). This ad's for you: The indirect effect of advertising perceptions on salesperson effort and performance. Journal of the Academy of Marketing Science, 41(1), 1-18. https://doi.org/10.1007/s11747-011-0293-y

Hui, C. (1994). Effects of leader empowerment behaviors and followers' personal control, voice, and self-efficacy on in-role and extra-role performance: An extension and empirical test of Conger and Kanungo's empowerment process model. Unpublished $\mathrm{PhD}$ dissertation, Indiana University, USA.

Ingram, T.N., LaForge, R., Avila, R., Schwepker Jr. C.H., \& Williams, M. (2012). Sales management: Analysis and decision making (8th ed.). Armonk, NY: M.E. Sharpe Inc.

Jaworski, B.J. (1988). Toward a theory of marketing control: Environmental context, control types, and consequences. Journal of Marketing, 52(3), 23-39. https://doi. org/10.2307/1251447

Jaworski, B.J., \& Kohli, A.K. (1991). Supervisory feedback: Alternative types and their impact on salespeople's performance and satisfaction. Journal of Marketing Research, 28(2), 190-201. https://doi.org/10.2307/3172807

Kohli, A.K., Shervani, T.A., \& Challagalla, G.N. (1998). Learning and performance orientation of salespeople: The role of supervisors. Journal of Marketing Research, 35(2), 263-274. https://doi.org/10.2307/3151853

Kwak, W.J. (2011). Multi-level investigation of empowering leadership, leader-member exchange, and subordinate empowerment. Unpublished $\mathrm{PhD}$ dissertation, Purdue University, USA.

Lambe, C.J., Webb, K.L., \& Ishida, C. (2009). Self-managing selling teams and team performance: The complementary roles of empowerment and control. Industrial Marketing Management, 38(1), 5-16. https://doi.org/10.1016/j. indmarman.2007.10.003

Lewis, M.W., \& Smith, W. (2014). Paradox as a metatheoretical perspective: Sharpening the focus and widening the scope. Journal of Applied Behavioural Sciences, 50(2), 127-149. https://doi.org/10.1177/0021886314522322

Miao, C.F. (2007). Salesforce control systems: An integrated approach. Unpublished PhD dissertation, University of Missouri-Columbia, USA.

Miao, C.F., \& Evans, K.R. (2013). The interactive effects of sales control systems on salesperson performance: A job demands-resources perspective. Journal of Academy of Marketing Science, 41, 73-90. https://doi.org/10.1007/s11747-0120315-4

Nash, R., Brown, D.A., \& Sutton, N. (2014). The paradox of management control and employee empowerment. Paper presented at the Interdisciplinary Perspectives on Accounting Conference, Cardiff Business School, UK. Retrieved 10 February 2015 from http://www.business.cf.ac.uk. 
Oliver, R.L., \& Anderson, E. (1995). Behavior and outcome-based sales control systems: Evidence and consequences of pure-form and hybrid governance. Journal of Personal Selling \& Sales Management, 15(4), 1-15.

Piercy, N.F., Cravens, D.W., \& Lane, N. (2012). Sales manager behavior-based control and salesperson performance: The effects of manager control competencies and organizational citizenship behavior. Journal of Marketing Theory and Practice, 20(1), 7-22. https://doi.org/10.2753/MTP1069-6679200101

Piercy, N.F., Cravens, D.W., \& Morgan, N.A. (1998). Salesforce performance and behaviour-based management processes in business-to-business sales organizations. European Journal of Marketing, 32(1/2), 79-100. https://doi. org/10.1108/03090569810197480

Piercy, N.F., Cravens, D.W., \& Morgan, N.A. (1999). Relationships between sales management control, territory design, salesforce performance and sales organization effectiveness. British Journal of Management, 10(2), 95-111. https://doi.org/10.1111/1467-8551.00113

Piercy, N.F., Low, G.S., \& Cravens, D.W. (2004). Consequences of sales management's behavior and compensation-based control strategies in developing countries. Journal of International Marketing, 12(3), 30-57. https://doi.org/10.1509/ jimk.12.3.30.38102

Piercy, N.F., Low, G.S., \& Cravens, D.W. (2011). Country differences concerning sales organization and salesperson antecedents of sales unit effectiveness. Journal of World Business, 46(1), 104-115. https://doi.org/10.1016/j.jwb.2010.05.022

Podsakoff, P.M., MacKenzie, S.B., Lee, J.Y., \& Podsakoff, N.P. (2003). Common method biases in behavioral research: A critical review of the literature and recommended remedies. Journal of Applied Psychology, 88(5), 879-885. https:// doi.org/10.1037/0021-9010.88.5.879

Porter, S.S., Wiener, J.L., \& Frankwick, G.L. (2003). The moderating effect of selling situation on the adaptive selling strategy: Selling effectiveness relationship. Journal of Business Research, 56(4), 275-281. https://doi.org/10.1016/S01482963(02)00440-X

Ringle, C.M., Wende, S., \& Becker, J-M. (2015). SmartPLS 3. Bönningstedt: SmartPLS. Retrieved 21 March 2018 from http://www.smartpls.com

Robinson Jr., L., Marshall, G.W., Moncrief, W.C., \& Lassk, F.G. (2002). Toward a shortened measure of adaptive selling. Journal of Personal Selling \& Sales Management, 22(2), 111-118.

Roman, S., \& Iacobucci, D. (2010). Antecedents and consequences of adaptive selling confidence and behavior: A dyadic analysis of salespeople and their customers. Journal of the Academy of Marketing Science, 38(3), 363-382. https://doi. org/10.1007/s11747-009-0166-9

Rouzies, D., \& Macquin, A. (2003). An exploratory investigation of the impact of culture on sales force management control systems in Europe. Journal of Personal Selling and Sales Management, 23(1), 61-72.

Scott, S.G., \& Bruce, R.A. (1994). Determinants of innovative behavior: A path model of individual innovation in the workplace. Academy of Management Journal, 37(3), 580-607. https://doi.org/10.2307/256701 
Simintiras, A.C., Ifie, K., Watkins, A., \& Georgakas, K. (2013). Antecedents of adaptive selling among retail salespeople: A multilevel analysis. Journal of Retailing and Consumer Services, 20(4), 419-428. https://doi.org/10.1016/j. jretconser.2013.04.004

Singh, R., \& Das, G. (2013). The impact of job satisfaction, adaptive selling behaviors and customer orientation on salesperson's performance: Exploring the moderating role of selling experience. Journal of Business \& Industrial Marketing, 28(7), 554-564. https://doi.org/10.1108/JBIM-04-2011-0121

Smith, W.K., \& Lewis, M.W. (2011). Toward a theory of paradox: A dynamic equilibrium model of organizing. Academy of Management Review, 36(2), 381-403. https:// doi.org/10.5465/amr.2009.0223

Spiro, R.L., \& Weitz, B.A. (1990). Adaptive selling: Conceptualization, measurement, and nomological validity. Journal of Marketing Research, 27, 61-69. https://doi. org/10.2307/3172551

Stan, S., Evans, K.R., Arnold, T.J., \& McAmis, G.T. (2012). The moderating influence of organizational support on the development of salesperson job performance: Can an organization provide too much support? Journal of Personal Selling \& Sales Management, 32(4), 405-419. https://doi.org/10.2753/PSS0885-3134320401

Sujan, H. (1986). Smarter versus harder: An exploratory attributional analysis of salespeople's motivation. Journal of Marketing Research, 23(1), 41-49. https:// doi.org/10.2307/3151775

Sujan, H., Weitz, B.A., \& Kumar, N. (1994). Learning orientation, working smart, and effective selling. The Journal of Marketing, 58(3), 39-52. https://doi. org/10.2307/1252309

Tannenbaum, R., \& Schmidt, W.H. (1973). How to choose a leadership pattern. Harvard Business Review, 51(3), 162-180.

Vecchio, R.P., Justin, J.E., \& Pearce, C.L. (2010). Empowering leadership: An examination of mediating mechanisms within a hierarchical structure. The Leadership Quarterly, 21(3), 530-542. https://doi.org/10.1016/j.leaqua.2010.03.014

Verbeke, W., Dietz, B., \& Verwaal, E. (2010). Drivers of sales performance: A contemporary meta-analysis. Have salespeople become knowledge brokers? Journal of the Academy of Marketing Science, 39(3), 407-428. https://doi.org/10.1007/s11747010-0211-8

Wang, G., \& Netemeyer, R.G. (2002). The effects of job autonomy, customer demandingness, and trait competitiveness on salesperson learning, self-efficacy, and performance. Journal of the Academy of Marketing Science, 30(3), 217-228. https://doi.org/10.1177/0092070302303003

Weitz, B.A. (1978). Relationship between salesperson performance and understanding of customer decision making. Journal of Marketing Research, 15(4), 501-516. https://doi.org/10.2307/3150621

Weitz, B.A. (1979). A critical review of personal selling research: The need for a contingency approach. In G. Albaum \& G. Churchill (Eds.), Critical issues in sales management: State-of-the-art and future research needs (pp. 76-126). Eugene, OR: College of Business Administration, University of Oregon. 
Weitz, B.A. (1981). Effectiveness in sales interactions: A contingency framework. The Journal of Marketing, 45(1), 85-103. https://doi.org/10.2307/1251723

Wren, B.M., \& Simpson, J.T. (1996). A dyadic model of relationships in organizational buying: A synthesis of research results. Journal of Business \& Industrial Marketing, 11(3/4), 63-79. https://doi.org/10.1108/08858629610125478

Zoltners, A.A., Sinha, P., \& Lorimer, S.E. (2008). Sales force effectiveness: A framework for researchers and practitioners. Journal of Personal Selling and Sales Management, 28(2), 115-131. https://doi.org/10.2753/PSS0885-3134280201

Zoltners, A.A., Sinha, P., \& Lorimer, S.E. (2009). Building a winning sales force: Powerful strategies for driving high performance. New York: AMACOM Division, American Management Association.

Zoltners, A.A., Sinha, P., \& Lorimer, S.E. (2013). Breaking the sales force incentive addiction: A balanced approach to sales force effectiveness. Journal of Personal Selling and Sales Management, 32(2), 171-186. https://doi.org/10.2753/ PSS0885-3134320201 